\title{
The Influence of Pedagogical Skill and Professional Competence in Teachers Performance of the Teacher in Primary Public Schools in Banyuasin I
}

\author{
Budi Rusdiono $^{1 *)}$, Edi Harapan ${ }^{2}$, Dessy Wardiah ${ }^{2}$ \\ ${ }^{1}$ SD Negeri 14 Banyuasin I \\ ${ }^{2}$ Universitas PGRI Palembang \\ *Corresponding author. Email: rusdionobudi@gmail.com
}

\begin{abstract}
This study aimed to determine and analyze the effect of teacher pedagogic competence and teacher professional competence on teacher performance. Based on research data and discussion in this study, it means that the teaching profession will greatly improve its performance if pedagogical competencies and professional competencies are continuously developed and applied in the learning process. Pedagogic competence and professional competence are competencies that every teacher must possess, and these two things play an important role in improving teacher performance. This research used a quantitative descriptive method with multiple linear regression equation analysis: $Y$ $=\mathrm{a}+\mathrm{b} 1 \mathrm{X} 1 \mathrm{~b} 2 \mathrm{X} 2+\mathrm{e}$. After researching SD Negeri teachers in Banyuasin 1 District, the results showed that pedagogic competence and professional competence positively affect SD Negeri Teachers' performance in Banyuasin 1 District. The results of this study can be justified for their truth and objectivity.
\end{abstract}

Keywords: Pedagogical Competence, Professional Competence, Teacher Performance

\section{INTRODUCTION}

Education is the spearhead of a country, a left behind or advanced country is dependent on educational conditions. The country will be developed and developed when the education sector becomes the key to developing a priority scale within a country. Indonesia's education procedure is defined in the national educational system Law No. 20 of 2003. Education to improve attitudes, skills [1].

The basic skills are needed to live in society. One of these components is the teacher. Teachers as professionals have a vision for the realization of the implementation of learning in accordance with the principles of professionalism to fulfill one's rights. It is the same for every citizen in obtaining a quality education. The status of the teacher as a learner depends, among other things, on the role of the teacher in education and learning, as facilitators, motivators, stimulators, learning engineers, and inspirers Learning for students. This role requires teachers to improve performance and Professionalism in line with changing demands that arise against Education World. Teacher professionalism is often associated with three factors Quite important, It includes teaching skills, teaching and technical allowances for teachers. The teacher is responsible for the outcomes of infant learning by means of interactive instruction. In addition to understanding the subject being learned, the instructor must master the fundamentals of learning [2].

In accordance with Government Regulation Number 74 of 2008 concerning Teachers which states that: Pedagogic competence, as referred to in paragraph (2) is the teacher's ability in managing students learning, which at least includes: (a) Understanding educational insight or foundation; (b) understanding learners; (c) curricular or program development; (d) design learning; implementing educational and dialogic learning; (f) using learning techniques; (g) assessing learning results; and (h) developing students in a way which actualizes vs. teaches and provides them with the ability to manage students' learning. It has efforts to deepen understanding of these students are based on the awareness that their talents, interests, and abilities vary so that individual services also vary. Not with standing the presentation in the same class, it always comes individually when it comes to an understanding. The teacher must know the level of individual differences in order for students can guide students whose learning acceleration is retarded, so that teaching-learning, therefore the teacher must master the 
principles of learning in addition to mastering the material being taught. In accordance with Government Regulation Number 74 of 2008 concerning teachers ,which states that: Pedagogic competence as referred to in paragraph (2) is the teacher's ability in student learning management, which at least includes:(a) understanding education insights or foundations, (b) learners' understandings, (c) curriculum or curriculum development, (d) design education, the implementation of training and dialogue-based learning, (f) use of learning technology, (g) assessment of the learning outcomes, etc. Notwithstanding the presented in the same class, but when it comes to an understanding individually, the teacher must know the level of individual differences to guide students whose learning acceleration is retarded. There are several criteria that the teacher cannot meet.

Based on interviews conducted with several teachers in Banyuasin I on Saturday, August 25, 2020 in the principal's room, The author found several problems concerning pedagogical competence teachers, including: (1) some teachers only use learning media That is in school and does not develop it; (2) lack of understanding teachers towards the conditions and characteristics of students, and (3) lack parental attention to students makes the teacher difficult teach. Teacher professional competence is a number of competencies associated with a profession that requires a variety of expertise in the field education or teacher training as a basic ability of teachers. Understanding will include the importance of the teacher's role as educators. They should grow the awareness that the teacher's job is not just a conveyor of knowledge. Teachers must be qualified to serve as instructors for activity organisers. Teachers of technical competence according to Government Regulations No. 74 of 2008 relating to teachers who say that: The professional skill of the instructor in compliance with the standard material of the instructional unit, subjects and/or category of subjects to be trained is the capacity to master scientific science, technology, and/or the community that it contributes to at least involve mastery of (a) subject matter extensive and in-depth; (b) intellectual overshadowing, or consistent with the academic unit curriculum, eye classes, or groups of subjects to be learned, with relevant science, technical and creative disception techniques. The teacher is active in the planning, implementation of and information on the monitoring and assessment of programs so that there is a change in itself which helps to improve the quality of education services in schools.

Based on this understanding of professional competence, There are several criteria a teacher must have in order to be said to have a good one. However, there are still several criteria what the teacher hasn't been able to fulfill. Based on the interviews conducted with teachers in Banyuasin 1 on Tuesday, August 25, 2020, in the teacher's room, the author found several related problems teacher professional competence, including: (1) some teachers have not mastered it ICT-based means; (2) some teachers have not used a variety of methods and models in learning, and (3) some teachers have not implemented CAR. By having these two competencies, the teacher is expected able to carry out their duties as professional educators because education and learning are not only intended to provide children various kinds of science and technology (learning to know) as well as what is needed in his life (learning to do), but education must be able to deliver learners to understand themselves well (learning to be) and can understand, respect others properly and adequately, so they are can live together in a very diverse society (learning to live together). To achieve the expected quality of education, of course that is must be implemented is to improve teacher performance. Teacher performance maximum is a dream for all schools, as well as for SD Negeri Banyuasin I. However, based on preliminary observations made to school principals that teachers' performance in SD Negeri Kecamatan Banyuasin I still needs to be improved, this shows that $70 \%$ of teachers have different performance. One of the differences is based on the background the competencies possessed by each teacher include: first, the teacher's ability in designing learning plans that suit students' abilities in the classroom still needs to be improved. It is necessary to form the learning process, and create an educational learning process creative and interactive at the same time. The other is teaching media that has not adequate causes the interaction between teachers and students the teaching and learning process becomes passive. Third, the absence of teaching expertise in IT and communication technologies, especially for some older teachers, as well as a lack of teacher participation in activities so that the teacher's ability to determine how to deliver the material and The management of teaching and learning interactions will be greatly reduced.

\section{METHODS}

This research is conducted using a quantitative approach. The data collection techniques were used in this research method questionnaire (questionnaire Questionnaire This study gave 65 questions and will be given to the teachers teaching in Banyuasin Subdistrict 1. Spread of Tourism during the epidemic covid19 will use its online system via WhatsApp to teachers who were used as research samples. For the weighting of the cangket, each choice was assessed. To interprete the data, it is necessary to know the highest pass (X) and the lowest (Y). The evaluation value is : $\mathrm{Y}=$ highest Likert score number of panels $\mathrm{X}=$ lowest Likert score number. Formula Index $\%=$ Total Score $/ \mathrm{Y}^{*} 100$. The interval (distance) and interpretation of the half-marker must be known. Find out the judgments by the method of searching intervals of percent (I). The Interval formula is as follows: $\mathrm{I}=100$ / Total Score (Likert) [3]. 
This study's population were all sub-districts of Banyuasin, Population selection with consideration to see pedagogical competence on the undergraduate students' performance.

This study's sampling technique uses simple random sampling, taking samples from 162 persons using a note without paying attention to the strata (level) in the member 67 population. Simple random sampling in this study was conducted using the "Cointoss" lottery, the researcher chooses some samples from $\mathrm{N}$ population which is done randomly [3].

\section{RESULTS AND DISCUSSION}

1. The impact of teacher performance in pedagogical expertise $\left(\mathbf{X}_{1}\right)$. The findings of the initial hypothesis test will suggest that the pedagogical skills of teaching success have a positive impact.

It is seen that, in line with the analyses, interviews and documentary studies of scholars, the higher the effectiveness of pedagogy skill and higher the success of the instructor as a result of pedagogy skills. Teachers have excellent teaching competence because they master teaching materials, design learning plans well, and can manage the class very well. The learning competences that include the supervision of pupils, preparation and the design of the learning process are crucial to the progress of the learning process [4] [5] [6].

\section{The Effect of Professional Competence $\left(\mathbf{X}_{2}\right)$ on Teacher Performance ( $Y$ )}

As results of testing the second hypothesis, can be concluded that there is the influence of professional competence on teacher performance. Conclusion It shows that the higher the teacher's professional competence, the higher the teacher's performance will be better in competency results professional teachers according to the results of observations, interviews, and studies documents conducted by researchers. Teachers have professional competence what is very good is proven by mastery and appreciation of the task professional must do. Professional competence as a part of teacher competence reflects the duties and obligations of the teacher that must be carried out in connection with the meaning of a teacher's office that demands professionalism, that is, a professional teacher is a competent teacher [7] [8] [9]. Competence professional refers more to the appearance of a teacher in mastering the material the lessons he taught. Teachers who can master the subject matter at the field of study that he teaches are broad and deep Self-confidence is more stable when standing in front of the class. Being a master in a good subject matter will also motivate teachers to show the quality of their performance and be professional simultaneously. In teachers' professional development, it has not been optimal in conducting self-evaluation, have a learning journal, and attend training/education and training [10] [11].

\section{Influence of teacher competence $\left(X_{1}\right)$ and of professional competence $\left(\mathrm{X}_{2}\right)$}

The results of testing for the third hypothesis can be concluded that competence pedagogic and professional competence jointly have Effect on teacher performance. Based on the F-test results, which shows F-count significant, Ho was rejected and accepted Ha. So the working hypothesis (Ha) in this study which reads "there is an influence Pedagogic competence and professional competence of teachers together regarding the performance of SD Negeri teachers in Banyuasin 1, it is accepted. Pedagogic competence is a must owned by a teacher and plays an important role in teacher assessment performance [12] [13]. Appraisal performance of students in schools requires pedagogical competence that is done, implemented and produced by teachers in schools, can accountability for truth and objectivity. So it's pretty clear that Pedagogic competence has a positive direct effect on teachers' performance in SD in Banyuasin 1. Teachers of SD Negeri-Banyuasin 1 who have high pedagogical competence are proven to understand tasks the principal that it carries starts from the planning compilation process learning, implementing the learning process, evaluating learning, and in developing the curriculum properly so as to produce performance [14] [15].

\section{CONCLUSION}

Based on the results of research and discussion of the influence of competence Pedagogy and Professional Competence of Teachers on Teacher Performance in Schools basic Negeri Se Banyuasin 1 district, the conclusion can be drawn as following: 1) the results of testing the first hypothesis can be concluded that there is pedagogic competence on teacher performance. With The test results for the pedagogic competence variable $\left(\mathrm{X}_{1}\right)$ obtained the sig value 0.004 . The sig value is less than the probability value $(0.05)$, or value $0.004<0.05$. So it can be concluded that these results indicate that The higher the teacher's effective pedagogic competence, the higher the teacher's performance; 2) the results of testing the second hypothesis can be concluded that there is professional competence on teacher performance. With The test results for the variable professional competence $\left(\mathrm{X}_{2}\right)$ obtained a value Sig 0,000 . The sig value is less than the probability value $(0.05)$, or value $0.000<0.05$. So it can be concluded that these results indicate that the higher teacher's professional competence, the higher teacher's performance; 3) the results of testing the third hypothesis can be concluded that competence pedagogic and professional competence together positively influence teacher performance. 4 . the $\mathrm{F}$ test calculation shows that $\mathrm{F}$ count $=12.416>\mathrm{F}$ table $=3.32$ With $\mathrm{a}$ 
significance of $0.000<0.05$. This result shows that $F$ is significant, and 4) the combination of pedagogical competence, teacher professional competence, Taken together, it is proven to influence performance teacher. This means that the combination of better pedagogical competence and teachers' professional competence will improve teacher performance.

\section{ACKNOWLEDGMENTS}

Our deepest gratitude goes to Teachers in SD Negeri 14 Banyuasin I, Chancellor of Palembang PGRI University, Director of the Postgraduate Program of PGRI Palembang University and the Education Management Study Program of PGRI Palembang University, who have supported us in doing this extraordinary thing. This project is funded independently. We also want to thank our Education Management friends who helped us a lot in a short time frame to complete this project.

\section{REFERENCES}

[1] Marlina, A., Rachman, A., \& Alkornia, S. (2013). Psykologi Pendidikan. Yogyakarta: PT. Tiara Wacana

[2] Alkornia, S. (2016). Studi Deskriptif Kompetensi Pedagogik dan Profesionalisme Guru Paud Dharma Wanita Binaan SKB Situbundo. Jurnal Pancaran”. Vol. 5, No. 4, 143-158.

[3] Arikunto, S. (2013). Prosedur Penelitian Suatu Pendekatan Praktik. Jakarta : Rineka Cipta.

[4] Barnawi \& Arifin, M. (2014). Kinerja Guru Profesional: Instrumen Pembinaan, Peningkatan dan Penelitian. Ar-Rusz Media : Yogyakarta

[5] Duwi. P. (2016). Belajar Alat Analisis Data Dan Cara Pengolahannya Dengan SPSS Praktis dan Mudah Dipahami untuk Tingkat Pemula dan Menengah. Yogyakarta: Gava.

[6] Echols, J. (2010). Kamus Indonesia-Inggris. Jakarta: Gramedia

[7] Kalu, M. Ridwan. (2016). Kompetensi Pedagogik dan Profesional Guru sekolah Dasar yang Tersertifikasi Pada Pembelajaran Sains, “Jurnal Sains dan Teknologi Tadulako". Volume 5 Nomor 3 Hal. 85-94.

[8] Mardalena, Arafat Y., \& Fitria, H. (2020). Pengaruh Supervisi Akademik dan Kompetensi Profesional Guru Terhadap Kinerja Guru da SMA Tanjung Raja. Jurnal Intelektualita: Keislaman, Sosial dan Sains. Vol 9 No 1, 103-114.
[9] Mulyasa, E. (2017). Uji Kompetensi dan Sertifikasi Guru. Bandung: PT Remaja Rosdakarya.

[10] Peraturan Pemerintah Republik Indonesia Nomor 74 tahun 2008 tentang Guru

[11] Sanjaya, W. (2011). Perencanaan dan Desain Sistem Pembelajaran. Jakarta: Kencana Prenada Media grup.

[12] Sappaile, N. (2017). Pengaruh Kompetensi Pedagogik, Kompetensi professional, dan sikap Profesi Guru Terhadap Kinerja Penilaian Guru di Sekolah Dasar. Jurnal Teknologi Pendidikan. Volume 19, Nomorl, hal 47-58.

[13] Susilowati, I., Dkk. (2013). Strategi Peningkatan Kompetensi Guru dengan Pendekatan analysis Hierachy Process," Journal of economics and Policy" Vol. 6 (1) Hal. 80-92.

[14] Winarni, W. E. (2018). Teori dan Praktik Penelitian Kuantitatif Kualitatif (Penelitian Tindakan Kelas (PTK), Research and Development (R \& D).

[15] Yirizki, D. (2018). Kompetensi Pedagogik dan Profesional Guru dalam Peningkatan Hasil Belajar Fisika Peserta Didik SMAN di Wilayah Barat Kabupaten Bireuen" Jurnal Pendidikan Sains Indonesia”. Vol. 06. No. 02, 68-74. 